\title{
Failure to detect $o$-diphenoloxidase in cultivable mycobacteria obtained from feral armadillos
}

\author{
K PRABHAKARAN, E B HARRIS \& \\ W F KIRCHHEIMER \\ US Public Health Service Hospital, Carville, LA 70721, USA
}

Received for publication 28 February 1980

\begin{abstract}
Summary We reported earlier that Mycobacterium leprae separated from lepromatous human as well as armadillo tissues contains an unusual form of $o$-diphenoloxidase which oxidized several diphenols, including $\mathrm{D}$ - and L-DOPA (3,4-dihydroxyphenylalanine) to quinones in vitro. It was not known whether any other species of mycobacterial separated from infected armadillo tissues would show $o$-diphenoloxidase activity. Recently, a few feral armadillos with mycobacterioses caused by cultivable bacilli became available. The data presented in this report demonstrate that cultivable mycobacteria obtained from the tissues of wild-caught armadillos did not contain the enzyme. Two species of nocardia tested converted DOPA to pigment, but this reaction was found to be non-enzymatic, being unaffected by heating. On the other hand, $O$-diphenoloxidase of the leprosy bacilli was sensitive to higher temperatures. Visual evidence on the occurrence of the enzyme in M. leprae is also presented.
\end{abstract}

\section{Introduction}

We have shown earlier that suspensions of Mycobacterium leprae purified from infected human or armadillo tissues contain the enzyme $o$-diphenoloxidase (EC 1.10.3.1), which actively oxidizes a variety of phenolic substrates including D- and L-DOPA (3,4-dihydroxyphenylalanine) (Prabhakaran \& Kirchheimer, 1966; ${ }^{1}$ Prabhakaran et al., 1975). ${ }^{2}$ In its wide substrate-specificity, resistance to inhibition by reducing agents and certain metal chelators, and in its kinetic properties, the bacterial enzyme was different from the $o$-diphenoloxidase occurring in vertebrate melanocytes (Prabhakaran, 1971; ${ }^{3}$ Prahhakaran et al., 1976). ${ }^{4}$ At the time of our previous studies (Prabhakaran et al., 1975), ${ }^{2}$ we did not have any controls using other species of mycobacteria separated from armadillo tissues. Recently, a few wild-caught animals were found to have 
mycobacterioses caused by cultivable organisms. The mycobacteria separated from the infected tissues of feral armadillos and the organisms grown in culture did not contain $O$-diphenoloxidase. Data are also presented on the enzymatic nature of the oxidation of D-DOPA by $M$. leprae and the absence of the enzyme in two species of nocardia.

\section{Materials and methods}

\section{O R G A N I S M S}

Mycobacterium leprae was separated from the infected spleen or lymph nodes of armadillos, as described earlier (Prabhakaran et al., 1976). ${ }^{4}$ The organs were removed aseptically during autopsy and held at $0^{\circ} \mathrm{C}$, before being homogenized in $0.2 \mathrm{M}$ sucrose, using a Braun Model 853-202 homogenizer. The bacilli were separated by differential and density-gradient centrifugations in solutions of sucrose $(0.2 \mathrm{M}$ and $0.3 \mathrm{M})$ and $\mathrm{KCl}(1.5 \mathrm{M})$. The bacterial suspension was washed twice with cold saline and twice with deionized, glass-distilled water. All the operations were carried out at $0-4^{\circ} \mathrm{C}$. The organisms were counted by the method of Hanks et al. (1964). ${ }^{5}$ The same procedure was used for separating the cultivable mycobacteria from the spleen, lymph node or liver of feral armadillos. The bacilli were grown in Dubos' medium at $37^{\circ} \mathrm{C}$ for 3 weeks, harvested by centrifugation, and washed with saline and water. Four species of mycobacteria have been isolated from the tissues of the armadillos: M. simiae, M. scrofulaceum, $M$. avium and $M$. terrae. Nocardia asteroides (ATCC 19247) was grown for 2 weeks in Dubos' medium at $25^{\circ} \mathrm{C}$, and $N$. brasiliensis (ATCC 19296) at $37^{\circ} \mathrm{C}$. The cultured organisms remained viable and showed good respiratory activity.

\section{CHEMIC A L S}

DL-DOPA $\left(\mathrm{G}^{3} \mathrm{H}\right), 250 \mathrm{mCi} / \mathrm{mmol}$ was purchased from Amersham, Arlington Heights, Ill, USA; glass counting vials from Beckman, Fullerton, Calif, USA; the scintillation solution, Aquasol from New England Nuclear, Boston, Mass, USA, and D-DOPA from ICN, Cleveland, Ohio, USA. Other chemicals used were of the highest purity commercially available.

\section{ENZYME ASSAY}

Oxidation of D-DOPA was assayed spectrophotometrically by measuring the absorbance of the quinone formed in the reaction (Prabhakaran et al., 1976). ${ }^{4}$ The reaction system was as follows: $\mathrm{Na}_{2} \mathrm{HPO}_{4}-\mathrm{KH}_{2} \mathrm{PO}_{4}$ buffer ( $\mathrm{pH} 6.8$ ), $0.1 \mathrm{M}$ (final concentration); D-DOPA, $0.002 \mathrm{M}$; bacilli, $5 \times 10^{9}$; volume, $3 \mathrm{ml}$; 
temperature, $37^{\circ} \mathrm{C}$; time, 60 minutes. The oxidation of ${ }^{3} \mathrm{H}$-DOPA was determined as described before (Harris \& Prabhakaran, 1975), ${ }^{6}$ where the activity of tritiated water formed from labelled DOPA was measured in a liquid scintillation counter. The organisms were heated at $100^{\circ} \mathrm{C}$ for 15 minutes, and cooled in an ice bath. To study the heat-sensitivity of $o$-diphenoloxidase of Mycobacterium leprae, the bacterial suspensions were exposed to different temperatures in an oven; the maximum duration of the exposure was 15 minutes to ensure complete inactivation of the enzyme. Each experiment was done at least 3 times, except in the case of bacilli separated from the tissues of feral armadillos. With these organisms, the experiments were done once each, because only limited amounts of material were available. However, the assays were repeated when the mycobacteria were grown in culture. For each bacterial suspension, the results did not show variations exceeding 10\%; the data presented are for representative experiments.

\section{Results}

C ULTIVABLE MYCOBACTERIA FROM FERAL ARMADILLOS

The bacilli separated from the tissues of feral armadillos and the same organisms grown in culture failed to oxidize DOPA (Table 1). Sufficient bacteria for the assay were recovered from the tissues of 3 armadillos. However, the bacilli

Table 1. Oxidation of DOPA by mycobacteria from feral armadillos: absorbance $480 \mathrm{~nm}$ $\left(\mathrm{X} 10^{-3}\right)$

\begin{tabular}{lccr}
\hline \multicolumn{1}{c}{ Bacilli } & $\begin{array}{c}\text { Unheated bacilli, } \\
\text { + DOPA }\end{array}$ & $\begin{array}{c}\text { Hea ted bacilli, } \\
+ \text { DOPA }\end{array}$ & DOPA \\
\hline $\begin{array}{l}\text { Separated directly from: } \\
\text { Spleen }\end{array}$ & 8 & 12 & 8 \\
$\quad$ Liver & 8 & 12 & 10 \\
Lymph node & 10 & 15 & 14 \\
Grown in culture from & & & \\
Spleen (M. simiae) & 20 & 30 & 10 \\
Liver (M. scrofulaceum) & 15 & 21 & 10 \\
Lymph node (M. terrae) & 20 & 22 & 10 \\
Lymph node $(M$. avium) & 8 & 12 & \\
\hline
\end{tabular}

were cultured from the tissues of many more animals. The slight activity observed with the bacteria was apparently not enzymatic, since heating the organisms failed to inactivate the reaction. This is in contrast to what was observed with Mycobacterium leprae where the activity was completely lost on heating. The data show that cultivable mycobacteria obtained from host tissues do not contain $o$-diphenoloxidase. The results corroborate our earlier finding 
that $o$-diphenoloxidase of $M$. leprae is not due to tissue components adsorbed by the organisms, but is an intrinsic property of the bacilli.

Even with the highly sensitive radiometric method using labelled DOPA, little activity was observed in a culture of $M$. scrofulaceum isolated from the lymph node of an armadillo (Table 2). However, M. leprae readily oxidized the tritiated substrate.

Table 2. Oxidation of tritium-labelled DOPA by Mycobacterium leprae and $M$. scrofulaceum

\begin{tabular}{lcl}
\hline Bacilli & $\mathrm{p} \mathrm{mol}{ }^{3} \mathrm{H}-\mathrm{DOPA}$ oxidized* \\
\hline $\begin{array}{l}\text { M. scrofulaceum } \\
\text { M. leprae }\end{array}$ & 0.35 \\
${ }^{*}$ Values corrected for & 59.70 \\
DOPA
\end{tabular}

\section{NON-ENZYMATIC OXIDATION OF DOPA BY NOCARDIA}

The oxidation of DOPA by $M$. leprae was compared to that observed with two species of nocardia. After centrifugation of the reaction mixtures, the spectra of the supernatant fractions were measured. The pigment formed from DOPA by nocardia gave a broad peak in the region $540-580 \mathrm{~nm}$. The quinone formed from DOPA by $M$. leprae showed maximum absorbance at $475-480 \mathrm{~nm}$ (Table 3). The reaction observed with nocardia was not inactivated by heat, indicating that it is a non-enzymatic process, stimulated by inorganic ions. $o$-Diphenoloxidase which is heat-labile is the only exzyme that oxidizes DOPA to pigment. With M. leprae, heated bacilli showed no oxidation of DOPA.

Table 3. Comparison of the oxidation of DOPA by Mycobacterium leprae and Nocardia sp.: (absorbance $\times 10^{-3}$ ).

\begin{tabular}{lcccc}
\hline \multicolumn{1}{c}{ Organisms } & $\begin{array}{c}\text { Wavelength } \\
(\mathrm{nm})\end{array}$ & $\begin{array}{c}\text { Unheated } \\
\text { organisms } \\
\text { + DOPA }\end{array}$ & $\begin{array}{c}\text { Heated } \\
\text { organisms } \\
\text { + DOPA }\end{array}$ & DOPA \\
\hline N. asteroides & 560 & 60 & 55 & 12 \\
N. brasiliensis & 560 & 60 & 64 & 10 \\
M. leprae & 480 & 73 & 10 & 12 \\
\hline
\end{tabular}

VISUAL EVIDENCE OF $o$-DIPHENOLOXIDASE IN $M$. leprae

Unheated or heated $M$. leprae suspensions were incubated with or without DOPA. In the tube containing unheated bacilli and DOPA, the reaction mixture developed an intense dark colour, due to oxidation of the diphenol to pigment (Figure 1a). The tubes containing unheated bacilli or heated bacilli with or 
without DOPA showed little colour change. Under the experimental conditions used, the substrate did not undergo auto-oxidation.

After incubation for 60 minutes, the reaction mixtures (except the one with DOPA, which remains in solution) were centrifuged at $25,000 \mathrm{~g}$ for 30 minutes. The precipitate in the tube containing unheated bacilli and DOPA was black; part of the pigment formed from DOPA sedimented with the bacilli (Figure 1b). The precipitate in the tubes containing unheated or heated bacilli alone or heated bacilli with DOPA showed no colour change. Evidently the $o$-diphenoloxidase of $M$. leprae is not catalysed by inorganic ions.

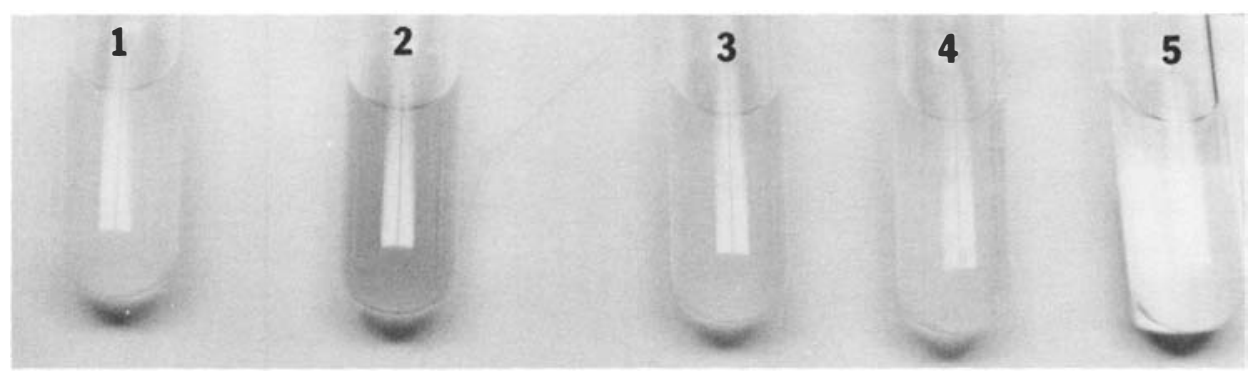

Figure 1 a. $o$-Diphenoloxidase in Mycobacterium leprae: before centrifugation of the reaction mixtures. From left to right: 1, unheated bacilli; 2, unheated bacilli + DOPA; 3, heated bacilli + DOPA; 4, heated bacilli; 5, DOPA.

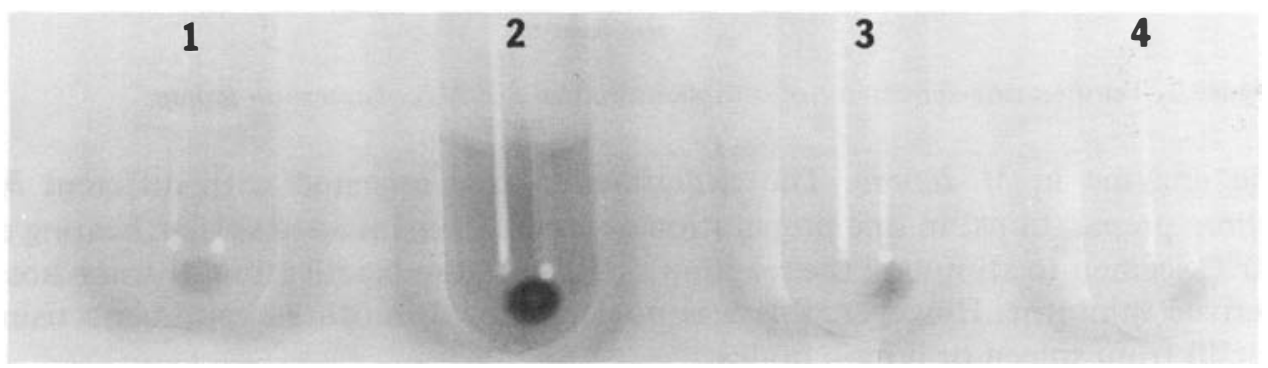

Figure 1b. $o$-Diphenoloxidase in Mycobacterium leprae: after centrifugation of the reaction mixtures. From left to right: $1-4$ same as Figure la; sample 5 being a solution, was not centrifuged.

\section{HEAT-SENSITIVITY OF $o$-DIPHENOLOXIDASE IN $M$. Leprae}

The bacterial suspensions were exposed to different temperatures and tested for oxidation of D-DOPA. There was a gradual loss of activity from $37^{\circ} \mathrm{C}$ to $80^{\circ} \mathrm{C}$, a sharp drop at $90^{\circ} \mathrm{C}$, and at $100^{\circ} \mathrm{C}$ the enzyme was inactivated 


\section{K Prabhakaran et al.}

completely. The decrease in activity was $21.6 \%$ at $60^{\circ} \mathrm{C}, 39.2 \%$ at $80^{\circ} \mathrm{C}$, and $72.5 \%$ at $90^{\circ} \mathrm{C}$ (Figure 2). The bacilli were heated for varying periods at $100^{\circ} \mathrm{C}$. There was complete loss of $o$-diphenoloxidase even when the exposure time was as low as 2 or 3 minutes, indicating the extreme temperature-sensitivity of

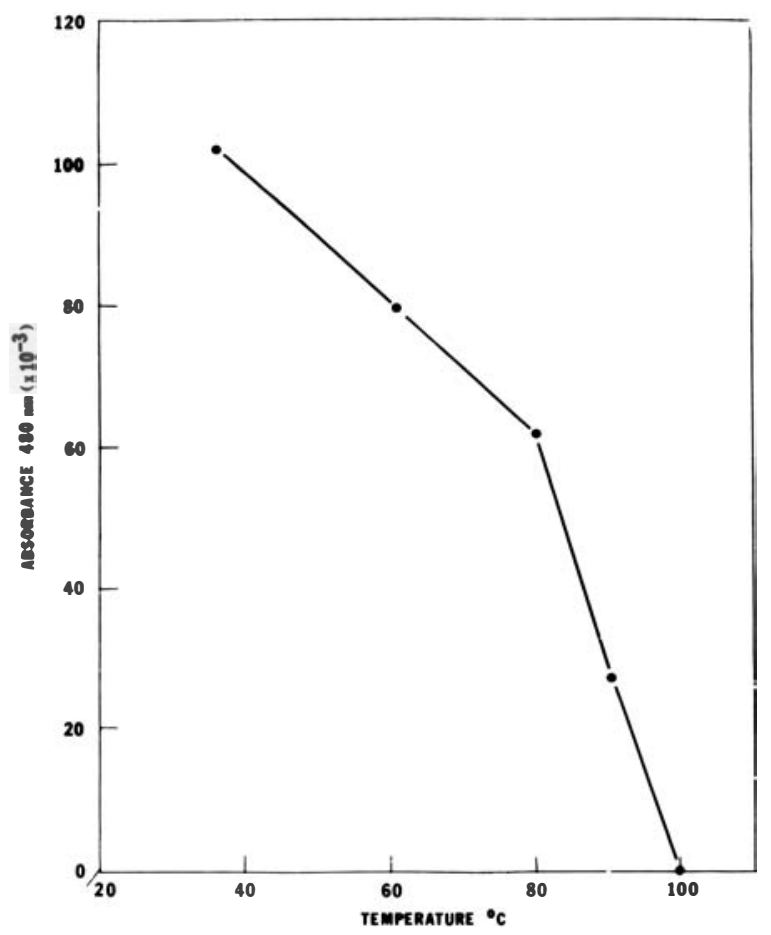

Figure 2. Temperature-sensitivity of $o$-diphenoloxidase of Mycobacterium leprae.

the enzyme in $M$. leprae. The experiments were repeated with different $M$. leprae preparations. In one preparation obtained from infected spleen, heating at $60^{\circ} \mathrm{C}$ seemed to stimulate the reaction, indicating the inactivation of some hostderived inhibitor. However, this was not confirmed in other experiments using bacilli from spleen or lymph nodes.

\section{Discussion}

For the first time, we show that cultivable acid-fast bacteria separated from the organs of feral armadillos with mycobacterioses, do not possess $O$ diphenoloxidase. As such, the oxidation of phenolic substrates by Mycobacterium leprae prepared from the organs of experimentally infected armadillos could not be due to host tissue elements adsorbed on the bacilli. The 
oxidation of DOPA by $M$. leprae is catalysed by $o$-diphenoloxidase which is a temperature-sensitive enzyme. The non-enzymatic conversion of the diphenol to pigment by the cultured organisms is probably caused by inorganic ions adsorbed from the media; the activity was not abolished on heating.

Certain precautions have to be observed to demonstrate $o$-diphenoloxidase in $M$. leprae obtained from lepromatous tissues. The tissues have to be held at $0^{\circ} \mathrm{C}$ or below and the preparative procedures done in the cold to prevent enzyme denaturation. When the armadillo tissues are stored for over 2 months, the bacilli gradually lose the enzyme activity. If the bacterial preparation is contaminated with host tissue material, no enzyme activity would be detected (Prabhakaran et al., 1979). ${ }^{7}$ Some suspensions of M. leprae prepared from infected armadillo liver might have a dark-brown or greenish tinge, indicating the presence of bile pigments. Such preparations do not oxidize DOPA, while bacilli separated from the spleen or lymph nodes of the same animal would be active. Probably, this phenomenon depends on the degree of liver damage in the individual animal. Occasionally we have found that leprosy organisms separated from the subcutaneous nodules of armadillos are hard to purify and would show very little enzyme activity. We have not encountered such discrepancies in $M$. leprae derived from human tissues. Cultures of mycobacteria used for testing DOPA oxidation have to be grown in liquid media and washed thoroughly to exclude false positive results. Control experiments using heated bacilli should be done, to determine non-enzymic conversion of DOPA to pigment by metal ions. To detect enzymatic oxidation of dopa by $M$. leprae, prolonged incubation of the reaction mixtures at $37^{\circ} \mathrm{C}$ is unnecessary. The substrate would undergo little auto-oxidation if the incubation conditions are properly controlled. In our experience, quinone formation from DOPA can be observed within 15 minutes if the bacterial suspension is enzymatically active. Failure to observe these precautions would, in fact, lead to anomalous results (Binford et al., 1977; $;^{8}$ Kato et al., 1976). ${ }^{9}$

In our previous experiments where $M$. leprae was derived from frozen tissues, the pigment produced from DOPA gave a peak at $540 \mathrm{~nm}$, characteristic of indole-5,6-quinone (Prabhakaran et al., 1976). ${ }^{4}$ In recent experiments where bacilli separated from fresh tissues were used, the peak was near $480 \mathrm{~nm}$, characteristic of dopachrome. The enzyme was heat-labile in both cases. A decarboxylation step is involved in the conversion of dopachrome to indole-5,6quinone. Probably, a decarboxylase is associated with the bacilli from frozen tissues. The reason for this variation remains to be elucidated.

We have shown earlier that $\beta$-glucuronidase detected in $M$. leprae preparations is adsorbed from the host tissue (Prabhakaran et al., 1978). ${ }^{10}$ However, $O$-diphenoloxidase seems to be a constitutive enzyme of the bacillus. So far, we have tested $M$. leprae for $O$-diphenoloxidase after five passages in the armadillo, and the bacilli have retained the activity unimpaired. Our efforts to induce the enzyme in two species of cultivable mycobacteria did not succeed 
(Prabhakaran et al., 1969). ${ }^{11}$ The species-specificity of DOPA metabolism for M. leprae (Kirchheimer \& Prabhakaran, 1968) ${ }^{12}$ has been corroborated by other workers and is being used as an identification test of the bacillus (Ambrose et al., 1974,13 ${ }^{13}$ Hall \& Rightsel, 1978 ${ }^{14}$ Kohsaka et al., 1978). ${ }^{15}$ Melanocytes do not lose $o$-diphenoloxidase in spite of repeated passages in vitro (Prabhakaran et al., 1975); ${ }^{2}$ it is likely that the leprosy bacteria would retain the activity, even if it were possible to grow the organisms in a bacteriological medium.

\section{Acknowledgements}

We thank Gregory T McCormick for growing the nocardias; Rita M Sanchez and J P Pasqua for providing the mycobacterial cultures.

\section{References}

Prabhakaran K, Kirchheimer WF. Use of 3,4-dihydroxyphenylalanine oxidation in the identification of Mycobacterium leprae. J Bacteriol, 1966, 92, 1267-8.

2 Prabhakaran K, Harris EB, Kirchheimer WF. $o$-Diphenoloxidase of Mycobacterium leprae separated from infected armadillo tissues. Infect Immun, 1975, 12, $267-9$.

${ }^{3}$ Prabhakaran K. Unusual effects of reducing agents on $O$-diphenoloxidase of $M y c o$ bacterium leprae. J Bacteriol, 1971, 107, 787-9.

${ }^{4}$ Prabhakaran K, Harris EB, Kirchheimer WF. Hypopigmentation of skin lesions in leprosy and occurrence of $o$-diphenoloxidase in Mycobacterium leprae. In Riley V (ed.), Pigment Cell, Vol. 3, pp. 152-64. Basel: S. Karger, 1976.

5 Hanks JH, Chatterjee BR, Lechat MF. A guide to the counting of mycobacteria in clinical and experimental materials. Int $J$ Lepr, 1964, 32, 156-67.

6 Harris EB, Prabhakaran K. Uptake of radioactive dopa by Mycobacterium leprae in vitro. Microbios, 1975, 12, 119-24.

7 Prabhakaran K, Harris EB, Kirchheimer WF. Metabolic inhibitors of host-tissue origin in Mycobacterium leprae. Lep India, 1979, 51, 348-57.

8 Binford CH, Meyers WM, Walsh GP, Storrs EE, Brown HL. Naturally acquired leprosy-like disease in the nine-banded armadillo (Dasypus novemcinctus); histopathologic and microbiologic studies. J Reticuloendothelial Soc, 1977, 22, 377-88.

9 Kato L, Ishaque M, Adapoe C. Oxidation of 3,4-dihydroxyphenylalanine by connective tissue constituents. Int J Lepr, 1976, 44, 435-42.

10 Prabhakaran K, Harris EB, Kirchheimer WF. Absence of $\beta$-glucuronidase in Mycobacterium leprae and elevation of the enzyme in infected tissues. Lep Rev, 1978, 49, 203-13.

11 Prabhakaran K, Kirchheimer WF, Harris EB. Oxidation of phenolic compounds by Mycobacterium leprae and inhibition of phenolase by substrate-analogue and copper chelators. J Bacteriol, 1969, 95, 2051-3.

12 Kirchheimer WF, Prabhakaran K. Metabolic and biologic tests on mycobacteria once labeled as leprosy bacilli. Int $J$ Lep $, 1968,36,162-5$. 
13 Ambrose EJ, Antia NH, Khanolkar SR. Uptake of radioactive dopa by Mycobacterium leprae. Nature (Lond), 1974, 249, 854-5.

14 Hall MFS, Rightsel WA. Growth of Mycobacterium leprae in macrophage-like cell cultures in diffusion chambers (personal communication), 1978.

15 Kohsaka K., Mori T, Ito T. Lepromatoid lesion developed in nude mouse inoculated with Mycobacterium leprae. La Lepro, 1976, 45, 177-87. 